\title{
ACHIEVEMENTS OF THE INSTITUTE OF CHEMISTRY OF THE ACADEMY OF SCIENCES OF MOLDOVA AT 50 YEARS ANNIVERSARY
}

\author{
Tudor Lupascu, Pavel F. Vlad, Aculina Aricu*, Maria Cocu \\ Institute of Chemistry of the Academy of Sciences of Moldova, Chişinău, \\ MD-2028, 3 Academiei str., Republic of Moldova \\ Tel: +7 (373 2) 739963; Fax: +7 (373 2) 739775; E-mail:aricu_aculina@yahoo.com
}

\begin{abstract}
This communication deals with the appearance and development of the research in the field of chemistry in the Republic of Moldova; at the beginning - in chemistry sections of Moldovan Branch of the USSR Academy of Sciences and then - at the Institute of Chemistry, founded in 1959. The dynamics of changes in the structure and research subjects is traced. Data are presented concerning the research results in the field of the chemistry of coordination compounds, fine organic synthesis, natural products chemistry, physicochemical analysis, quantum chemistry, mineral resources, chemistry of natural water and purification of waste water, the preparation and utilization of active carbons, and ecological chemistry. A detailed account both of basic research and applied investigation is given. The collaboration of our scientists with their colleagues from abroad is considered. Information is presented related to the scientific schools at our institute, its guidance and laboratory's leaders. The scientific equipment of the institute is mentioned. The relationship of the institute with higher schools, as well as training of young researchers will be presented.
\end{abstract}

Keywords: Institute of Chemistry, development, research, investigations, collaboration, equipment.

Sustainable development of the society would be impossible without the implementation of the achievements of modern chemical technologies for the needs of industry, agriculture, medicine, for treatment and valorization of wastes and analytical control of pollutants in the environment. All this appears to be especially important for our country that has no mineral resources.

Chemical investigations started in the Republic of Moldova in 1951, in the analytic group attached to the Section of Pedology of the Moldovan Branch of the former USSR Academy of Sciences with the research in the field of chemistry of coordination compounds of cobalt. This research significantly developed after the formation of the Section of Inorganic Chemistry of the Moldovan Branch of the of the former USSR Academy of Sciences in 1956, and even more due to the setting up of the Institute of Chemistry on 15 April 1959, which became, and still remained, the main centre of chemistry science and developments in the republic.

The basis of scientific directions of the Institute was created by famous researchers, members of the Academy, founders of scientific chemistry schools in Moldova: A.V. Ablov (1905-1978) - school of coordination compounds chemistry; G. V. Lazurievski (1906-1987) - school of organic and bioorganic chemistry, Iu. S. Lealicov (1909-1976) school of polarography, organizer and leader of research related to physical-chemical methods of analysis.

Later, new scientific schools were created: of quantum chemistry - headed by academician I. Bersuker; of bioorganic chemistry, chemistry of natural and physiologically active compounds - headed by academician P. Vlad; of chemistry of coordination, macrocyclic and supramolecular compounds - headed by academician N. Gărbălău; of ecological chemistry - headed by academician Gheorghe Duca and bioinorganic chemistry - headed by the corr. member of the ASM C. Turtă. The chemistry of natural and modified adsorbents, mainly of activated carbon, is being successfully developed by the school of dr. habilitate in chemistry, Professor T. Lupascu.

Scientific studies performed at the Institute of Chemistry are related to such fields as inorganic chemistry (chemistry of coordination compounds), organic chemistry, quantum and physical chemistry, analytical chemistry - branches of chemistry founded and ascertained since the beginning of the Institute's activity, in particular, and of chemical science in Moldova, in general.

Besides basic research the institute also carries out applied investigations: the obtaining of coordination compounds with useful properties for industry and agriculture (dyes for textile and plastic, ion-selective electrodes, the catalysts for epoxi-resins polimerization, the obtaining of extrapure metals, growth stimulators for plants etc), odorous compounds for perfumery and tobacco industry, production of essential oils, pharmacologically active compounds, development of methods of analysis and purification of natural and waste waters, development of electrochemical methods of metals dosing in environmental objects, and others.

The Institute devotes much attention to the training and education of young researchers. At the institute activate three specialized Scientific Councils for conferring scientific degrees of doctors and doctors habilitate (in inorganic; organic and bioorganic chemistry, and chemistry of natural and physiologically active compounds).

The institute carries out joint research with higher education establishments of our country. Many collaborators are also delivering courses at local universities. 
During the years, the institute passed through several structural and research-related reforms.

Now the Institute of Chemistry of the ASM includes the Centre of Physical chemistry and Nanocomposites, created in 2006, and 4 individual laboratories: of Coordination chemistry, Chemistry of terpenoides, Organic synthesis, and Ecological chemistry. The Centre includes 5 laboratories: Bioinorganic chemistry and Nanocomposites, Physicochemical methods of research, Quantum chemistry and chemical kinetics, Magnetic resonance and Laser spectroscopy, Atomic spectroscopy. The laboratories of the Institute have modern equipment, computers, connected to the internet, a scientific library. During the last 4 years, modern scientific equipment has been purchased, such as: IR, UV/Vis, NMR and Mossbauer spectrometer, elemental analyzer, autosorb, Stopped Flow spectrophotometer, digital Polarimeter and so on.

The scientific potential of the Institute of Chemistry is represented by 103 scientific researchers, including - 3 Full Members, 2 Corresponding Members, 16 Doctors Habilitate and 42 Doctors of Chemistry.

The Institute of Chemistry collaborates with various teams from abroad:

Romania: „Politehnica”University, Bucharest; National Institute of Materials Physics, Bucharest; Institute ECOIND, Bucharest; „C. D. Nenițescu” Institute of Organic Chemistry of the AS of Romania, Bucharest; „,G. Murgulescu” Institute of Physical Chemistry of the AS of Romania, Bucharest; "P. Poni”" Institute of Macromolecular Chemistry of the AS of Romania, Iasi; „A. I. Cuza” University, Iasi; „Gh. Asachi” University, Iasi;

Russia: Institute of Physical Chemistry and Electrochemistry of the AS of Russia; the Association of science and production „Neorganica” from the city of Electrostali, Moscow region; Institute of Technical Physics, Kazani;

USA: Department of Chemistry and Biochemistry, University of Texas at Austin; Centre for Marine Sciences (CMS), University of North Carolina at Wilmington;

France: Laboratory of synthesis and study of systems of biological interest and Laboratory of molecular and macromolecular photochemistry, University Blaise Pascal, Aubiere Cedex;

Ukraine: Institute of Colloidal Chemistry and Water Chemistry of the NAS of Ukraine;

Poland: Chemistry Faculty of „A. Mickiewicz” University, Poznań; Institute of Physical Chemistry, the AS of Poland; "A. Pawin" Institute of Biochemistry and Biophysics, Polish Academy of Sciences, Warszawa;

Belarus: Institute of Bioorganic Chemistry of the National Academy of Sciences of Minsk;

Holland: Agrarian University from Vageningen;

Spain: Department of Organic Chemistry, Faculty of Pharmacy, University of Valencia, Valencia;

Italy: Institute of Biomolecular Chemistry, CNR, Pozzuoli (Na); Laboratorio di Chimica Bioorgabica Universita degli Studi di Trento;

Germany: University of Leipzig, Institute of Organic Chemistry, Leipzig.

The collaboration of our researchers with scientific teams from abroad is strengthened by scientific conferences with international participation, organized by the institute.

At present, joint scientific research is carried out in the framework of several international projects:

one joint research project - ASM and Russian Foundation for Basis Research; one joint research project - ASM and Belarussian Republican Foundation for Fundamental Research; three joint research project - ASM and the Federal Ministry of Education of Germany (BMBF); two INTAS projects, including one INTAS- Moldova project, and one SCOPES project.

The Institute of Chemistry organized a series of international conferences. The most important are: the $\mathrm{I}^{\text {st }}$ to the $\mathrm{XVI}^{\text {th }}$ International Conferences on „Physical methods in coordination and supramolecular chemistry” that take place every 3 years, the Ist $^{\text {st }}$ and the II $^{\text {nd }}$ International Conferences of the Chemical Society of Moldova on „Realizations and perspectives of modern chemistry" held on 6-8 October 2003 and 1-3 October 2007, respectively.

Researchers who took part in those conferences were from 13 European countries: England, Austria, Belgium, Belarus, France, Germany, Greece, Holland, Poland, Romania, Russia, Spain, Ukraine, and the USA.

In 2006 the Institute of Chemistry began publishing the journal „Chemistry Journal of Moldova” in English.

The most important results of research

\section{Chemistry of coordination compounds}

Investigations in the field of chemistry of coordination compounds significantly developed after1956 with the formation in of the Section of Inorganic Chemistry of the Moldavian Branch of the Academy of Sciences of the USSR, named in 1975 the Laboratory of Chemistry of Coordination Compounds. Initially, the scientific theme was oriented towards the synthesis and investigations of coordination compounds of transition metals, especially, of cobalt, copper, nickel, iron, palladium; to investigations of the structure and properties of compounds of this class, using physical methods of investigation and quantum chemistry computation methods. Later, the range of research themes was enlarged significantly, including studies in the field of template processes, topochemical synthesis, in non-aqueous medium and other conditions characteristic to the process of obtaining new mono- and polynuclear coordination compounds, including ones with macrocyclic and chelating ligands with programmed properties; synthesis of biologically active coordination compounds of biometals; development of the theory of physical methods of investigation of coordination compounds; development of the theory of the electronic and vibronic structure of compounds with mixed valence, 
enhancement of quanto-chemical methods of investigation, and of methods of molecular design of biologically active systems, with a special focus on the mechanisms of their action.

Due to the utilization of the electronic absorption spectra in a series of cobalt(III) transdioximines, the phenomenon of isomerisation was discovered and later confirmed by the separation of crystalline compounds and by detailed investigations of their properties. Research was also performed in the field of chemistry of coordination compounds of transition metals with thiosemicarbasones. It was the first time that metal complexes with selenosemicarbazide and various selenosemicarbazones were obtained and studied. During the investigation of magnetic properties of $\mathrm{Fe}(\mathrm{III})$ coordination compounds with thiosemicarbazones using methods based on magnetic susceptibility and the gamma resonance effect, the electron spin isomerism was discovered at several chelates. Systematic research was performed regarding $\mathrm{Cu}(\mathrm{II})$ complex compounds with carboxylic, hydroxy carboxylic and amino acids. Complexes of lantanides with organic amines were synthesized and studied. A new direction in magnetochemistry was developed - the theory of magnetic exchange interaction in polynuclear clusters, which allowed describing more adequately the temperature dependence of their magnetic susceptibility and electronic spin resonance spectra.

The synthesis of physiologically active and catalytically active complexes of microelements on the basis of diketones and dioximes with bioligands was carried out. The complexes of cobalt(III) dioximines with sulfamides were synthesized.

After the passing away of academician Antonie Ablov (1978), academician Nicolae Garbalau became head of the Laboratory of Chemistry of Coordination Compounds, who was the founder of the scientific school in the field of chemistry of coordination compounds, macrocyclic and supramolecular compounds. Research in the field of chemistry of coordination compounds includes the elaboration of modern concepts in coordination and supramolecular chemistry, study of new complexes of 3d-elements with organic polyfunctional ligands. Investigations are related to: directed synthesis using original procedures of new mono- and polynuclear coordination and supramolecular compounds of transition metals with chelating and macrocyclic ligands, determination of their structure and specific properties, including practically useful ones.

Concepts and fundamental laws of template assembly of macrocyclic and supramolecular systems, including highly polynuclear clusters, were elaborated.

In 2006, after the decease of academician Nicolae Gărbălău, dr. hab. Ion Bulhac was elected head of the laboratory.

Fundamental results are presented in over 620 articles and 4 monographs. On the basis of the conducted research, a number of elaborations were offered and protected by over 40 patents; these could be classified as follows: catalysts, colorants, stimulators of biological processes, new coordination compounds for obtaining extra-pure metals, ionselective electrodes, and anticorrosion coating agents.

\section{Bioinorganic Chemistry}

On 18 June 1975, according to the decision of the State Committee for Sciences and Technology of the Council of Ministries of the former USSR, research in a foremost direction was launched, which allowed the creation of a new Laboratory of Bioinorganic Chemistry, aimed at the study of biologically active coordination compounds. The dr. hab. Dumitru Batîr was elected as head of this laboratory (1974 - 1988).

The synthesis and study of coordination compounds of biometals is the basic task of the Bioinorganic Chemistry laboratory, headed at present by the corr. member of the ASM Constantin Turtă, the founder of the scientific school of bioinorganic chemistry, and of Mossbauer spectroscopy applications in chemistry. Investigations are related to: coordination compounds of biometals ( $\mathrm{Fe}, \mathrm{Co}, \mathrm{Mn}, \mathrm{Cu}, \mathrm{Zn}, \mathrm{Ni})$ with $\alpha$ - dioximes, Schiff bases and carboxylic acids, including amino acids, and determination of their molecular and crystalline structure. The molecular and crystalline structure of tri- and tetranuclear iron(III) clusters, mono- and dimmers of copper(II) with amino acids and of mononuclear dioximates of iron and cobalt were determined. The electronic structures of iron(II) and (III) dioximates, of homo- and heteronuclear clusters containing iron were determined, allowing a more adequate interpretation of spectra of such compounds. The electron delocalization in iron oxo-carboxylates with mixed valence and the spin isomerism for iron(III) dioximates were determined using Mossbauer spectroscopy and magnetochemistry. The obtained results were published in over 400 scientific papers.

Regarding the applicative area, coordination compounds possessing anticancer, antiviral, antibacterial, anticoccidal and antidote properties were revealed, as well as several growth regulators for plants and algae.

The preparation "Gajazot" with anti-chlorosis properties and the preparation „Cu-12" were recommended for implementation in viticulture. The elaborations are protected by 16 patents.

\section{Quantum chemistry}

Simultaneously with the creation of the institute and broadening the area of chemical investigations, a number of organizational measures were undertaken in order to apply physical methods of research and quantum-chemical computations in chemistry; thus the quantum group was created, and later, in 1962, reorganized into the Laboratory of quantum chemistry, headed by academician Isaak Bersuker, the founder of the scientific school of quantum chemistry. 
Research in the field of quantum chemistry was quite significant from the very beginning, being highly appreciated at the international level.

Computational studies of the electron-vibrational interactions were carried out - the effect and pseudo JahnTeller effect, new methods were elaborated and existing methods were enhanced, of as well as of electronic structure and properties of coordination compounds, and computation software programs were created and upgraded. The study of the influence of the electronic structure on nuclear configurations of polyatomic systems and their dynamics lead to the elaboration of a new concept in the theory of structure and particularities of polyatomic systems - the concept of vibronic interaction, which resulted in a scientific discovery, registered in 1978 in the State Registry of the USSR, no. 202: „Явление туннельных расщеплений уровней энергии многоатомных систем в состоянии электронного вырождения" (,, The Phenomenon of Tunneling Splitting of Energy Levels of Polyatomic Systems in Electronic Degenerate States") (I. Bersuker). On the basis of this scientific discovery, the vibronic theory of segnetoelectricity was developed. Special attention was focused to the catalysis theory, research being directed towards the study of the elementary catalytic act; new regularities in the formation of the crystalline structure were revealed (electronic crystallochemistry). The quanto-chemical interpretation of transinfluence was elaborated. Significant scientific results were achieved in the development of the theory of physical methods of investigation of materials structure and their peculiarities.

At present, the Laboratory of Quantum Chemistry is headed by dr. hab., professor Ivan Ogurțov. The following research has been performed: vibronic effects in coordination compounds stereochemistry; localization-delocalization effects in polynuclear coordination compounds and their development in spectroscopy; magnetic properties and the possibility of their utilization in molecular electronics; vibronic effects in crystallochemistry; vibronic effects and the activation of small molecules in catalytic chemical reactions; magnetism in polynuclear coordination compounds; calculation methods, semiempirical and ab initio calculations of coordination compounds electronic structure; the study of the structure-activity (chemical, biological etc.) relationship; computer modelling and design of biologically active compounds.

A new concept was postulated and developed in the frames of the theory of molecules and crystals - the theory of vibronic interactions; the polyelectronic quantum chemistry theory of dimer, trimer and tetramer clusters with mixed valence was elaborated.

\section{Chemistry of natural compounds}

Along with coordination chemistry, the chemistry of natural compounds and organic synthesis developed. The founder of these investigation was academician Gheorghe Lazurievski. The Organic Chemistry Section, founded in 1956, was the second structural unit of the Chemistry Institute, later named as the Laboratory of Chemistry of Natural Compounds (1959-1975). In 1975 this laboratory is divided into two: Laboratory of Chemistry of Steroidal Compounds (headed by the dr. in chemistry Petru Ciobanu) and the Laboratory of Chemistry of Isoprenoids (headed by the dr. in chemistry Dumitru Popa). In 1976, both laboratories were reorganized. The first one became the Laboratory of Chemistry of Ethero-oleaginous Plants (headed by academician Pavel Vlad), and the second one returned to its original line and has been headed ever since by Dumitru Popa, under the name of the Laboratory of Chemistry of Plants growth and development Regulators. In 1991 these two laboratories were unified into a single research unit- the Laboratory of Chemistry of Terpenoides, headed by academician Pavel Vlad.

Initially, research was related to the study of chemical composition of vegetal raw material and of wastes resulting from the industry of production of essential oils. Later, the area of scientific interest included fundamental research into new structural-selective and stereospecific methods of total and partial synthesis of terpenic polyfunctional compounds, first of all, related to the drimanic sesquiterpenoides class, that has a vast range of biological activity, and their multilateral investigation.

In the frameworks of investigations of alkaloid generating plants, detailed study of periwinkle, meadow-rue and buirush were performed, and several indole type alkaloids were extracted, two of which - brevicolin and brevicarin, were new compounds of the $\beta$-carbolynic series. Their structure and biogenesis were established, multiple chemical transformations of these compounds, including mutual transformations, were carried out.

Wastes from the essential oils production were used to obtain and study sclareol and 13-episclareol. Methods of their isolation were elaborated and a range of chemical reactions, such as oxidation, hydrocloruration, amination were studied; stereochemistry of diterpenoides from labdanic group was established, the preparation methods of valuable odorous compounds from sclareol were elaborated.

About 40 polyfunctionalized diterpenoids of clerodane structure were extracted and identified. They present taxonomic interest. Research related to the elaboration of plants-growth regulators, chemistry of odour compounds and essential oils were developed. Further, investigations were conducted on triterpenic saponines, as well as steroidal glycosides extracted from various plants.

For three decades, the team of organic and bioorganic chemists has been headed by academician Pavel Vlad, the founder of the scientific school of bioorganic chemistry, chemistry of natural and physiologically active compounds and fine organic synthesis. 
In the field of Chemistry of Terpenoides, under academicean Pavel Vlad'sguidance, the study of terpeniodes was performed. Investigations are related to labdanic and isoagatanic diterpenoides, drimanic sesquiterpenoides, norlabdanic compounds, scalaranic and heilantanic sesterterpenoids. The methods of their synthesis on the basis of the raw materials, isolated from vegetal wastes after the essential oils production, were elaborated.

Regarding fundamental studies, the cleavage products of a number of accessible labdanoids were investigated, the stereochemistry of a range of labdane compounds was revealed, semi-synthetic methods of preparation of a large number of drimanic sesquiterpenoids and norlabdanic derivatives were elaborated. The general, structure selective and stereospecific ways of the biomimetic synthesis of cyclic mono-, sesqui-, di- and sesterterpenoids have been performed by superacidic cyclization of the aliphatic precursors. New general reactions for organic chemistry were elaborated. The results of these investigations were published in over 350 publications.

In the field of applied research, the methods for the reduction of norambreinolide have been elaborated and implemented; new products such as ambrol, chetoxide, sclareoloxide, and ionoxide were prepared. Methods of sclareol isolation as well as of anetol-enriched fennel oil preparation were elaborated. Methods for the ozonolitic preparation of the norambreinolide and sclareoloxide were devised. More than 20 compounds, having strong ambergris odour with norlabdanic and homotrichinanic skeletons, were obtained. On the basis of these compounds, a range of original flavouring compositions suitable for tobacco aromatization were prepared, and several of drimanic compounds with biological activity were synthesized. These elaborations are protected by over 50 patents. Compounds of practical importance have been used in perfumery and tobacco industry. Now investigations are directed towards obtaining biologically active compounds for pharmacology.

\section{Organic chemistry}

In 1962, on the initiative of dr. Alexandr Samşurin, the Laboratory of Organic Synthesis was founded. The staff of that laboratory started its activity by obtaining preparations for pests control and of several compounds with attracting properties. During 1972 -1982 the Laboratory of Organic synthesis, named in 1976 as the Laboratory of Chemistry of Preserving compounds, was headed by dr. hab. Grigore Junghietu. In 1984 dr. Miron Krimer took the lead of the laboratory which was then named the Laboratory of Pesticides Chemistry, and in 1991 named again, the Laboratory of Organic synthesis. After the decease of the dr. Miron Krimer, the Laboratory of Organic Synthesis has been headed by dr. hab. Fliur Macaev.

Methods of the synthesis of heterocyclic indole derivatives from the respective pirilium salts were elaborated. The condensation reactions of indole and oxindole with ketones and keto-aldehydes were investigated in detail. Significant research was performed in the field of the synthesis of a number of attractants, juvenile hormones and phytoestrogens of cumestan series. A new method of the synthesis of pyrocarbonic acid esters was elaborated, and their several transformations were investigated. The method of the synthesis of 8 - oxyquinolin and its new derivatives was elaborated. Investigations were performed in order to obtain highly effective antibacterial preparations that could be used as food stabilizators. Physico-chemical properties of pectic compounds were studied, as well as the possibility of their use in winemaking.

The syntheses and chemical transformations of heterocyclic compounds are performed under the direction of dr.hab. Fliur Macaev. Investigations are related to aromatic hydrocarbons, heterocyclic compounds, alkaloids, steroids analogues of vitamin D, monoterpenes - carene, carvone. The methods of preparation of these natural compounds good sintons for obtaining of biologically active compounds were improved.

Regarding fundamental research, a detailed study of alkylation reactions using tosilates of several natural alcohols was carried out, conditions for the acetyl group migration from enol acetates were elucidated and the reactivity of resulted diketones was studied. Two new types of acid and alkaline recyclization of thiocarbamoilate derivatives of chinazolin-4-one were discovered, which allowed the synthesis of several new oxa(tia)diazoles.

In the applied area, methods of obtaining of several important preparations, used in food industry, agriculture and medicine were elaborated. The compounds with psycho- stimulating, anticonvulsant, sedative, tranquilizing, antimycotic and cardiac activity regulation properties were prepared. Also, compounds with a significant tuberculostatic activity were obtained. The methods of the synthesis of several intermediates in obtaining physiologically active compounds, Biotin (vitamin $\mathrm{H}$ ) and vitamin $\mathrm{D}_{3}$, were optimized.

The results of research are presented in over 200 scientific publications and protected by 30 patents.

\section{Analytical chemistry}

The Institute of Chemistry became an important centre of analytical chemistry - research direction founded by academician Iurie Lealicov. The Laboratory of Analytical Chemistry was founded in 1957 when Professor Iurie Lealicov laid the foundations of electrochemical methods of analysis.

In the frames of physico-chemical investigations, the theory and practice of polarography were investigated, as well as the kinetics of processes accompanied by the adsorption of metals complexes on the electrode, and the possibility of utilization of the effect of inhibition- acceleration of electrochemical reactions on the analysis of alloys, electrolytes, semiconductors, of waste waters, soil and air at industrial factories, of mineral clays, trace amounts of pesticides, of 
standard samples of nonferrous metals and alloys. The quanto-chemical computation of the system catalyst - activator - oxidant, was performed for the first time, which allowed a deeper understanding of the catalytic process mechanism. Several methods were proposed for the determination of compounds in various objects and media - soil, water, air, vegetal materials, and foodstuffs. Over 20 methods of determination of $\mathrm{Pb}, \mathrm{Cd}, \mathrm{Fe}, \mathrm{Cu}, \mathrm{Mo}$, As, Ti and other elements were devised, applicable to various objects that were widely applied in the national economy.

In 1973, dr. Ion Vatamanu was appointed head of the Laboratory of Analytical Chemistry (called the Laboratory of Electrochemical Methods of Investigation for a short period), and in 1991 dr. Ludmila Chiriac was elected head of laboratory. Methods and advanced techniques for the increase of selectivity and sensitivity of electrochemical methods of analysis were elaborated and tested under the guidance of dr. hab., professor Mihail Revenco. Catalytic currents and adsorption phenomena of species were used in voltammetry and stripping adsorptive polarography; chemical activation and carbon fibres microelectrodes electrochemistry were used for the determination of toxic metals in waters, soil.

Methods of analysis were developed for the determination of main components and of traces in electronic materials. The behaviour of several organic polydentate and polyfunctional reagents such as oxy acids, metalochromic indicators, thiazinic dyes, thiosemicarbazones was studied, in complex forming reactions, and the influence of these interactions on the selectivity and sensitivity of electrochemical methods of analysis of heavy metals was estimated. Efficient methods of the analysis of metals, such as $\mathrm{Pb}, \mathrm{Cu}, \mathrm{Cd}, \mathrm{Fe}, \mathrm{Ni}, \mathrm{Zn}$ and $\mathrm{Mo}$ applicable to foodstuffs and environmental objects were elaborated. New technologies of carbon fibre microelectrodes were proposed and tested in order to improve the sensibility and selectivity of toxic metals traces analyses.

\section{Ecological chemistry}

Recently, research in the field of ecological chemistry gained a significant importance; in our country this scientific direction was founded by academician Gheorghe Duca, the President of our Academy.

The scientific school founded by academician Gheorghe Duca revealed the fundamental mechanisms of homogeneous catalysis, developed the theory of redox phenomenon in the environment, elucidated the oxidation and reduction mechanisms during the formation of oenologic products quality; elaborated the concepts of physicochemical and biochemical treatment of waste waters, the technologies of wastes valorization, of production of medicinal preparations, cosmetic products, decrease of atmospheric nox, methods of estimation of chemical harm in case of pulmonary and gastro-intestinal cancer, has developed new procedures of obtaining biologically active compounds directly from winery by-products, ecological audit, ecological education, contributed to the creation of the redox concept regarding the action of peroxides on ecological systems etc.

The Laboratory of Ecological Chemistry of the Institute of Chemistry passed through three steps of its development. It was founded as the Laboratory of Chemistry of Mineral Resources, due to the fact that natural, mineral and vegetal resources are the main source of national wealth. The first head of the laboratory was dr. Nicolai Lobanov. The dr. Valeriu Ropot headed the laboratory, called then the Laboratory of Mineral Resources and Chemistry of Water.

Chemical and physico-chemical investigations were performed on the local bentonites, the chemical composition and adsorptive-structural properties of clays in the Republic Moldova were determined, as well as the conditions of thermal activation of bentonites that are used as natural sorbents for the purification of various liquids.

Investigations in the field of adsorbents and sorption of various toxic compounds, as well as the study of regularities of formation of water quality, resulted in the elaboration of purification technologies for various water categories and methods of their complex analysis, technologies of valorization of wastes obtained during water purification, elaboration on their basis of technologies for cyclic water utilization, preparation of activated carbons for medicinal use.

After the passing away of Dr.Valeriu Ropot, dr. habilitate Tudor Lupascu reorganised the Laboratory of Mineral Resources and Water Chemistry into the Laboratory of Ecological Chemistry.

Elaboration of procedures of adsorbents synthesis, determination of their adsorptive capacity and structural parameters, utilization of disperse systems for the protection of waters and human health - these are the main scientific directions in the field of Ecological Chemistry, being worked out under the guidance of dr. habilitate Tudor Lupaşcu. Investigations are related to: local vegetal subproducts, activated carbons obtained from these sources of raw material, mineral adsorbents, sources of natural and waste waters; technologies of water potabilization; medicinal preparations on the basis of activated carbons.

Theoretical and practical bases were elaborated for the synthesis of activated carbons from vegetal regenerable subproducts. The mechanism of adsorption of organic and inorganic pollutants on common and oxidized activated carbons was established. Procedures of natural and waste waters treatment were elaborated. Medicinal preparations on the basis of activated carbons were created and their capacity for human body detoxification was estimated. The processes of modification of mineral adsorbents and the possibility of their utilization for the immobilization of organic compounds and heavy metals from the aquatic medium were investigated. Compositions for covering interior walls of buildings on the basis of disperse systems were elaborated. The procedures of production of activated carbons 
and compositions for walls covering are protected by 12 patents. The processes and mechanisms of immobilization, migration, transformation of pollutants in the system water-suspensions were studied and ascertained for the waters in the case of the rivers Nistru and Prut.

The results of scientific investigations performed in the frames of the institute are presented in over 4300 scientific papers, including around 80 collective and individual monographs and thematic selections, over 240 author certificates and patents, over 120 technological elaborations have been introduced into the national economy.

Considering the current necessities of our country's development, the National Council of Accreditation certified the following scientific directions of the Institute of Chemistry (Certificate no. 004 Decision 14/AC on 16 February 2006):

1. Directed synthesis and study of coordination compounds with various useful properties.

Original methods of synthesis of mono- and polynuclear ones of transitional metals and biometals with polyfunctional and polydentate ligands will be elaborated and realized, leading to the broadening of fundamental knowledge of modern coordination chemistry and its new compartments - chemistry of macrocyclic and of supramolecular compounds; allowing to obtain new compounds with useful properties for microelectronics, textile industry, agriculture, medicine, veterinary.

2. Directed synthesis of organic biologically active compounds, including natural compounds.

Theoretical bases of fine organic synthesis will be developed, including that of natural compounds, especially drimanic sesquiterpenoides and labdanic diterpenoides and of heterocyclic derivatives which contain oxygen, nitrogen, sulphur. Original structural- and regioselective and stereospecific methods of the synthesis of the compounds mentioned above will be elaborated, using modern synthesis methods. The focus will be set on obtaining biologically active compounds potentially useful for medicine, industry and agriculture.

3. Investigation of chemical and physico-chemical processes, elaboration of methods for the analytical control of ecosystems and non-polluting technologies.

Theoretical bases will be elaborated for the elucidation of physico-chemical processes and mechanisms for the obtaining of adsorbents with well-defined properties. The processes and mechanisms of pollutants transformation and immobilization in aquatic systems will be ascertained. New methods and techniques of analytical control of chemicals in various environmental objects will be elaborated.

\section{Monographs}

[1]. Bersuker, I. B. and Ablov, A. V. Chemical Bonds in Complex Compounds, Academy of Sciences, MoSSR, Kishinev, 1962, 208 p.

[2]. Batîr, D. Dicționar chimic rus-moldovenesc. Editura"Cartea Moldovenească", Chişinău, 1963, 356 p.

[3]. Shamshurin, A. A.; Krimer, M. Z. Physico-chemical properties of organic chemical toxins and growth regulators. Moscow, «Nauka», 1966, 171p.

[4]. Берсукер, И. Б. Русско-молдавский физический словарь. Из-во Лумина, Кишинев, 1967, 400 с.

[5]. Влад, П. Ф.; Лазуревский, Г. В. Бициклические дитерпеноиды. РИО АН МССР, Кишинев, 1968,138 с.

[6]. Krimer, M. Z.; Shamshurin, A. A. Chemistry of the juvenile hormone and its analogues. Chisinau, Stiinta, 1970, $111 \mathrm{p}$.

[7]. Ляликов, Ю. С.; Булатов, М. И.; Бодю, В. И.; Крачун, С. В. Задачник по физико-химическим методам анализа. М., 1972. 217 с.

[8]. Жунгиету, Г. И. Оксоиндол и его производные. Кишинев, Штиинца, 1973, 192 с.

[9]. Чикрызова, Е. Г.; Бардина, С. М. Полярографические каталитические токи в растворе молибден(VI)хлорат калия щавелевая кислота. Теория и практика полярографических методов анализа. Кишинев, Штиинца, $1973.314 \mathrm{c}$.

[10]. Ляликов, Ю. С. Физико-химические методы анализа. М.: Химия, 1974. 536 с.

[11]. Ляликов, Ю. С.; Радауцан, С. И.; Копанская, Л. С.; Старуш, Т. Г. Аналитическая химия полупроводников. Кишинев, Штиинца, 1975. 217 с.

[12]. Ляликов, Ю. С.; Киссин, Б. И.; Тимохин, Г. А.; Ропот, В. М. Организация заводских химических лабораторий. М., 1975, 136 с.

[13]. Ляликов, Ю. С. Успехи и перспективы развития полярографического метода. Кишинев, Штиинца, 1975.

[14]. Ляликов, Ю. С. Новые направления в полярографии. Кишинев, Штиинца, 1975.

[15]. Жунгиету, Г. И.; Будылин, В. А.; Кост, А. Н. Препаративная химия индола. Кишинев. Штиинца, 1975, $264 \mathrm{c}$.

[16]. Bersuker, I. B. Electronic Structure and Properties of Coordination Compounds. Introduction to the Theory (Russ.), Second Edition, Chemistry, Leningrad, 1976, 350 p.

[17]. Shamshurin, A. A.; Krimer, M. Z. Physical-chemical properties of pesticides. Moscow, Chemistry, 1976, 327 p.

[18]. Popa, D. P. Higher terpenoids from the plants of the Labiatae family. Chisinau, Stiinta, 1976, 148 p. 
[19]. Чикрызова, Е. Г.; Хоменко, В. А. Потенциометрическое титрование с поляризованными электродами. Кишинев, Штиинца. 1976, 157 с.

[20]. Ляликов, Ю. С.; Хоменко, В. А.; Панарский, М. С.; Брацлавский, Ю. И. Автоматизация и механизация работ в химикоаналитических лабораториях. Кишинев, Штиинца, 1976. 136 с.

[21]. Ляликов, Ю. С.; Четыркин, В. В. Химия в народном хозяйстве Молдавии. Кишинев, Штиинца, 1976. $71 \mathrm{c}$.

[22]. Ляликов, Ю. С. Химия в часы досуга. Кишинев, Штиинца, 1977. 108 с.

[23]. Ватаман, И. И.; Мерян, В. Т.; Пинтилий, Б. Ф. и др. Электродные процессы, осложненные адсорбцией комплексов металлов на поверхности ртути. Кинетика и механизм гетерогенных и гомогенных процессов. Кишинев, Штиинца, 1977. 323 с.

[24]. Bersuker, I. B. Scientific Discovery: "The Phenomenon of Tunneling Splitting of Energy Levels of Polyatomic Systems in Electronic Degenerate States”, State Registered, USSR, 1978, with the priority from September 12, 1960. [Diploma N 202 issued in 1979] Official Bulletin of the State Committee on Inventions and Discoveries, N 40, October 1978.

[25]. Ж Жунгиету, Г. И.; Рехтер, М. А. Изатин и его производные. Кишинев, Штиинца, 1978, 229 с.

[26]. Жунгиету, Г. И.; Влад, Л. А. ЮГЛОН и родственные 1, 4-нафтохиноны. Кишинев, Штиинца, 1978,95 с.

[27]. Ляликов, Ю. С.; Клячко, Ю. А. Теоретические Основы современного качественного анализа. М.: Химия, 1978. $312 \mathrm{c}$.

[28]. Жунгиету, Г. И. Индоксил, его аналоги и производные. Кишинев, Штиинца, 1979. 127 с.

[29]. Ляликов, Ю. С.; Аранович, Г. И.; Коршунов, Ю. Н. Справочник по физикохимическим методам исследования объектов окружающей среды. Л., Судостроение. 1979. 647 с.

[30]. Ропот, В. М.; Ватаман, И. И.; Кирияк, Л. Г.; Чикрызова, Е. Г. Полярография в техническом анализе. Кишинев. Штиинца, 1979, 130 с.

[31]. Ляликов, Ю. С. Полярография в техническом анализе. Кишинев, Штиинца, 1979, 235 с.

[32]. Ляликов, Ю. С. Страницы жизни и творчества. Кишинев, Штиинца, 1980, 132 с.

[33]. Гэрбэлэу, Н. Реакции на матрицах, Кишинев, Штиинца, 1980, 184 с.

[34]. Батыр, Д., Ю. С. Ляликов. Страницы жизни и творчества. Кишинев, Штиинца, 1981, 131 с.

[35]. Popa, D. P.; Krimer, M. Z.; Cucicova, C. I.; Pasecinik, G. S.; Orgheian, T. M.; Reinbold, A. M. Utilization of growth regulators in plants growing. Chisinau, Stiinta, 1981, $158 \mathrm{p}$.

[36]. Popa, D. P.; Cucicova, C. I. Abscisic acid analogues. Chisinau, Stiinta, 1982, 70 p.

[37]. Батыр, Д. Каталитические реакции и охрана окружающей среды. Кишинев, Штиинца, 1983,272 с.

[38]. Берсукер, И. Б.; Полингер, В. З. Вибронные взаимодействия в молекулах и кристаллах Наука, Москва, $1983336 \mathrm{c}$.

[39]. Цукерблат, Б. С.; Белинский, М. И. Магнетохимия и радиоспектроскопия обменных кластеров, Кишинев, Штиинца, 1983, 280 с.

[40]. Vataman, I. I.; Fiştic, N. F. O sută de probleme la chimie. Chişinău, Ştiinţa, 1983, 125 p.

[41]. Junghietu, G. I.; Suvorov, N. N.; Kost, A. N. New syntheses in the indole series. Chisinau, Stiinta, 1983,117 p.

[42]. Батыр, Д. Русско-молдавский политехнический словарь. Кишинев, Главная редакция Молдавской Советской Энциклопедии 1983, 704 с.

[43]. Bersuker, I. B. The Jahn-Teller Effect and Vibronic Interactions in Modern Chemistry. Plenum Press, New York, 1984, 320 p.

[44]. Гэрбэлэу, Н.; Индричян, К. Масс-спектрометрия координационных соединений. Кишинев, Штиинца, 1984, $310 \mathrm{c}$.

[45]. Ed. Bersuker, I.B. The Jahn-Teller Effect. A Bibliographic Review, IFI/Plenum, New York, 1984,590 p.

[46]. Батыр, Д.; А. В.Аблов, Страницы жизни и творчества. Кишинев, Штиинца, 1986, 220 р.

[47]. Bersuker, I. B. Electronic Structure and Properties of Coordination Compounds, Third Edition, Chemistry, Leningrad, 1986, 288 p.

[48]. Жунгиету, Г. И.; Артеменко, А. И. Гидрохамовые кислота (N-гидроксиамиды) и их производные. Кишинев, Штиинца, 1986, 140 с.

[49]. Берсукер, И. Б. Эффект Яна-Теллера и вибронные взаимодействия в современной химии. Моscova. Наука, $1987,337 \mathrm{c}$.

[50]. Bersuker, I. B.; Polinger, V. Z. Vibronic Interactions in Molecules and Crystals.Springer-Verlag, Heidelberg_ 1988, 385 p.

[51]. Влад, П. Ф.; Колца, М. Н. Синтез и применение душистых веществ из лабдановых дитерпеноидов. Кишинев, Штиинца, 1988, 184 с.

[52]. Фиштик, И. Ф.; Ватаман, И. И. Термодинамика гидролиза ионов металлов. Кишинев, Штиинца, 1988, $294 \mathrm{c}$. 
[53]. Фиштик, И. Ф. Термодинамика сложных химических равновесий. Кишинев, Штиинца, 1989, 315 с.

[54]. Ватаман, И. И.; Кирияк, Л. Г.; Пономарева, Т.; Копанская, Л. С.; Мерян, В. Т.; Пинтилий, Б. Ф.; Грама, И. Д.; Баскин, В. Н. Полярография в аттестационном анализе стандартных образцов цветных металлов и сплавов. Кишинев, Штиинца, 1989, 107 с.

[55]. Гэрбэлэу, Н. В.; Арион, В. Б. Темплатный синтез макроциклических соединений, Кишинев, Штиинца, 1990, $374 \mathrm{c}$.

[56]. Ропот, В.М.; Стратулат, Г.В.; Санду, М.А.; Лупашку, Ф.Г.; Русу, В.И. и др. Проблемы качества, использования и охраны водных ресурсов ССР Молдова. Кишинев, Штиинца, 1991.-285 с.

[57]. Sandu, M.; Lozan, V.; Ropot, V. Metode şi instrucțiuni pentru controlul calitatății apelor. Chişinău, Ştiințta, 1992, $160 \mathrm{p}$.

[58]. Batîr, D. Dicționar de chimie şi tehnologie rus-român. Chişinău, Editura Enciclopedică „Gheorghe Asachi”, 1994.

[59]. Терентьева, И.В.; под ред. Влада, П. Ф. Жизнь моя химия растений. Кишинев, Штиинца, 1995,175 с.

[60]. Barbă, N. A.; Dragalina, G. P.; Vlad, P. F. Chimie organică. Chişinău, Ştiința, 1997, 722 p.

[61]. Gerbeleu, N. V.; Arion, V. B.; Burgess, J. Template synthesis of macrocyclic compounds. Weinheim, „WileyVCH", 1999, 565 p.

[62]. Pogrebnoi, I. L.; Pogrebnoi, S. I. Solving problems in organic synthesis. Chisinau, State University of Moldova, 2000, 256 p.

[63]. Editors: Lesczinski, J. I. B. Bersuker in Computational Chemistry: Reviews of Current Trends , V. 6, World Scientific, Singapore, 2001, pp 69-135.

[64]. Barbă, N.; Dragalina, G.; Vlad, P. Bazele teoretice ale chimiei organice. Hidrocarburile. Derivaţi halogenaţi. Chişinău, CEP USM, 2003, 230 p.

[65]. Turtă, Constantin. Introducere în spectroscopia de rezonanță gama. Chişinău, 2003, CEP USM, 171 p.

[66]. Galin, F. Z.; Lakeev, S. N.; Tolstikov, Gh. A.; Iskanderova, V. N.; Davletov, R. G.; Macaev, F. Z.; Mullagalin, F. Z.; Maydanova, I. O.; Abdullin, M. F.; Sahautdinov, I. M. Synthesis of biological active compounds via use of keto-stabilized sulfur ylides. In "Modern Organic Synthesis". Chemistry, Moscow. 2003, 419-438.

[67]. Macaev, F. Synthesis of spiroindolin-2-ones from 1H-indole-2,3-dione. In "Selected methods for synthesis and modification of heterocycles". Vol. 3. The chemistry of synthetic indole systems. IBS press, 2004, 75-102.

[68]. Batîr, Dumitru. Treptele unui urcuş. Chişinău, Ştiința, 2004, 176 p.

[69]. Lupaşcu, T. Cărbuni activi din materii prime vegetale. Chişinău, Ştiința, 2004, 224 p.

[70]. Rusu, V.; Lupaşcu, T. Chimia sedimentelor acvatice. Chişinău, Ştiinţa, 2004, 272 p.

[71]. Vlad, P.F. "Synthetic investigations in the field of drimane sesquiterpenoids" . In Studies in Natural Products Chemistry (Bioactive Natural Products). Part M, 2006, 33, 393-432, ed. by Atta-ur-Rahman, Elsevier Science Publishers.

[72]. Batîr, D. Neliniştea memoriei, Chişinău, Ştiința, 2007, 348 p.

[73]. Duca, Gheorghe. Contribuţii la societatea bazată pe cunoaştere. Chişinău, Ştiința, 2008, 288 p.

[74]. Editors: Boggs, James and Polinger, Victor. The Jahn-Teller effect and beyond. Selected Works of Isaac Bersuker with Commentaries. Published by the Academy of Sciences of Moldova. Tipografia AŞM, 2008,398 p.

[75]. Barbă, Nicanor; Dragalina, Galina; Vlad, Pavel. Compuşi hidroxilici, compuşi organici cu sulf, azot, fosfor. Indicații metodice. Chişinău, CEP USM, 2008, 154 p.

[76]. Ştefirța, A.; Brinza, L.; Toma, S.; Buceaceaia, S.; Melenciuc, M.; Bulhac, I.; Turta, C.; Zubarev, V.; Barbă, N.; Robu, S. Diminuarea impactului factorilor pedoclimatici extremali asupra plantelor de cultură. Chişinău, Tipografia A.Ş.M., 2008, p. 166-191. 